\title{
Aspek reproduksi ikan kakap Lutjanus vitta (Quoy \& Gainmard, 1824) di Teluk Jakarta dan sekitarnya
}

[Reproductive aspects of brownstripe red snapper Lutjanus vitta (Quoy \& Gainmard, 1824) in Jakarta Bay and its surroundings]

\author{
Selvia Oktaviyani ${ }^{\bowtie}$, Wanwan Kurniawan \\ Pusat Penelitian Oseanografi, LIPI \\ Jalan Pasir Putih 1, Ancol Timur, Jakarta Utara 14430
}

Diterima: 02 Juni 2016; Disetujui: 23 Mei 2017

\begin{abstract}
Abstrak
Kajian beberapa aspek reproduksi ikan kakap Lutjanus vitta (Quoy \& Gainmard, 1824) di Teluk Jakarta dan sekitarnya dapat menghasilkan informasi yang sangat penting dalam rangka pengelolaan sumber daya ikan tersebut. Tujuan penelitian ini adalah untuk menganalisis sebaran frekuensi panjang, nisbah kelamin, kematangan gonad, indeks kematangan gonad, ukuran kali pertama matang gonad, dan rata-rata panjang tertangkap ikan kakap. Penelitian dilaksanakan pada bulan April 2014 hingga Januari 2015 di Tempat Pelelangan Ikan (TPI) Tanjung Pasir, Tangerang. Aspek yang diamati meliputi panjang cagak dan bobot tubuh ikan, jenis kelamin, kematangan gonad, dan bobot gonad. Hasil penelitian menunjukkan bahwa ukuran panjang cagak ikan kakap berkisar antara 132-265 mm dengan nisbah kelamin dalam keadaan seimbang. Ikan kakap yang tertangkap didominasi oleh ikan yang belum matang gonad. Indeks kematangan gonad tertinggi terjadi pada bulan September 2014 yaitu 2\%. Ukuran panjang cagak kali pertama ikan matang gonad (Lm) adalah $252 \mathrm{~mm}$ (jantan) dan $187 \mathrm{~mm}$ (betina), serta panjang cagak rata-rata tertangkap (Lc) adalah $178 \mathrm{~mm}$. Kondisi ini dapat menyebabkan lebih-tangkap yang mengganggu tingkat pertumbuhan ikan kakap.
\end{abstract}

Kata penting: ikan kakap, kematangan gonad, nisbah kelamin, rata-rata panjang tertangkap, ukuran ikan kali pertama matang gonad

\begin{abstract}
Study on reproductive aspects of brownstripe red snapper Lutjanus vitta (Quoy \& Gainmard, 1824) in Jakarta Bay and its surroundings can obtain important information for fish resources management. The objective of this research is to analyze length frequency distribution, sex ratio, gonadal maturation, gonado somatic index, the length at first maturity $(\mathrm{Lm})$ and the average length of captured (Lc) for this fish. This research was conducted from April 2014 to January 2015 with sampling location in Tanjung Pasir Fishing Port, Tangerang. Fish sampling and of fish that were. The observed aspects included fork length, weight, sex, gonad maturity and gonad weight was done monthly. The result showed that the fork length of this fish ranged between 132-265 mm with the equal sex ratio. The capture fish are dominated by fish with immature stage. The highest of gonado somatic index was on September 2014 (2\%). The fork length at first maturity $(\mathrm{Lm})$ were $252 \mathrm{~mm}$ (male) and $187 \mathrm{~mm}$ (female) while the average fork length of captured (Lc) was $178 \mathrm{~mm}$. This condition can cause a growth overfishing.
\end{abstract}

Keywords: reproductive aspects, brownstripe red snapper, Jakarta Bay, gonad maturity, sex ratio, the average length of captured, the length at first maturity

\section{Pendahuluan}

Ikan kakap Lutjanus vitta (Quoy \& Gainmard, 1824) (Pisces: Lutjanidae) merupakan salah satu jenis ikan demersal yang hidup berkelompok di daerah terumbu karang atau perairan dengan dasar yang rata pada kedalaman 10-100 meter (Newman \& Williams 1996, Anderson \& Allen 2001; Ramachandran et al. 2013). Daerah

$\triangle$ Penulis korespondensi

Alamat surel: selvia.oktaviyani@gmail.com persebaran ikan kakap mencapai seluruh wilayah tropis, seperti di sebelah barat Samudera Pasifik, sebelah timur Samudera Hindia, Caledonia Baru dan Pulau Gilbert hingga ke selatan India dan perairan Jepang (Anderson \& Allen 2001).

Ikan kakap menjadi salah satu ikan komersial paling penting di laut tropis dan subtropis (Randall 1995), termasuk di Teluk Jakarta dan sekitarnya. Harga jual ikan kakap di Tempat Pelelangan Ikan (TPI) Tanjung Pasir, Tangerang cukup tinggi, bisa mencapai Rp. 30.000,00- 
$50.000,00 \mathrm{~kg}^{-1}$. Operasi penangkapan ikan dilakukan harian dengan alat tangkap yang beragam, seperti pancing rawai, pancing ulur, jaring insang atau trawl dasar. Permintaan pasar yang tinggi dengan nilai jual yang relatif besar mendorong nelayan untuk melakukan penangkapan ikan kakap secara intensif, sehingga dapat mengancam kelestarian sumber daya ikan tersebut.

Upaya pengelolaan sumber daya ikan kakap dapat diketahui melalui berbagai kajian penelitian, salah satunya adalah penelitian aspek reproduksinya. Penelitian mengenai hal tersebut telah banyak dilakukan di berbagai negara, seperti di perairan Australia Barat (Davis \& West 1992, Davis \& West 1993), Karang Penghalang Besar (Great Barrier Reef), Australia (Newman et al. 2000) dan India (Ramachandran et al. 2013). Namun di Indonesia, khususnya di perairan Teluk Jakarta dan sekitarnya, informasi tersebut masih sangat terbatas. Oleh karena itu, penelitian ini penting dilakukan agar diperoleh informasi yang dapat dijadikan sebagai dasar dalam pemanfaatan dan pengelolaan ikan kakap yang optimal. Penelitian ini bertujuan untuk menganalisis berbagai aspek reproduksi ikan kakap, meliputi sebaran frekuensi panjang, nisbah kelamin, tingkat kematangan gonad (TKG), indeks kematangan gonad (IKG), ukuran ikan kali pertama matang gonad (Lm), dan rata-rata panjang ikan tertangkap (Lc).

\section{Bahan dan metode}

Pengambilan ikan contoh dilakukan satu kali dalam sebulan pada bulan April 2014 hingga
Januari 2015, kecuali bulan Juni, Juli, Oktober, dan November 2014. Lokasi pengambilan contoh berada di TPI Tanjung Pasir, Kabupaten Tangerang. TPI ini berada di sisi barat Teluk Jakarta dan merupakan tempat pelelangan ikan yang cukup berkembang di Kabupaten Tangerang. Ikan contoh diambil secara acak dari hasil tangkapan nelayan pancing rawai. Nelayan biasa menggunakan ukuran mata pancing yang kecil dengan nomor mata pancing 13-15. Daerah penangkapan ikan oleh nelayan Tanjung Pasir adalah di sekitar Teluk Jakarta hingga ke Kepulauan Seribu, seperti Pulau Pari, Pulau Tikus, Pulau Tidung, dan Pulau Payung (Gambar 1). Kondisi daerah tersebut merupakan perairan dangkal dengan rata-rata kedalaman kurang dari 50 meter dan bersubstrat pasir atau lumpur berpasir serta terdapat ekosistem terumbu karang terutama di daerah sekitar Kepulauan Seribu, yang merupakan salah satu habitat ikan kakap dewasa.

Data yang dikumpulkan terdiri atas panjang cagak (fork length FL), bobot tubuh (W), tingkat kematangan gonad (TKG), dan bobot gonad $\left(\mathrm{W}_{\mathrm{g}}\right)$. Setiap ikan diukur panjang cagaknya dengan kaliper dalam satuan mm, sedangkan bobot tubuh ikan $(\mathrm{W})$ dan bobot gonad $\left(\mathrm{W}_{\mathrm{g}}\right)$ ditimbang dengan timbangan elektronik dalam satuan gram dengan ketelitian 0,1 g (bobot tubuh ikan) dan $0,01 \mathrm{~g}$ (bobot gonad). Penentuan jenis kelamin dilakukan secara visual berdasarkan perubahan morfologi gonad yang mengacu pada Holden \& Raitt (1974) (Tabel 1). 


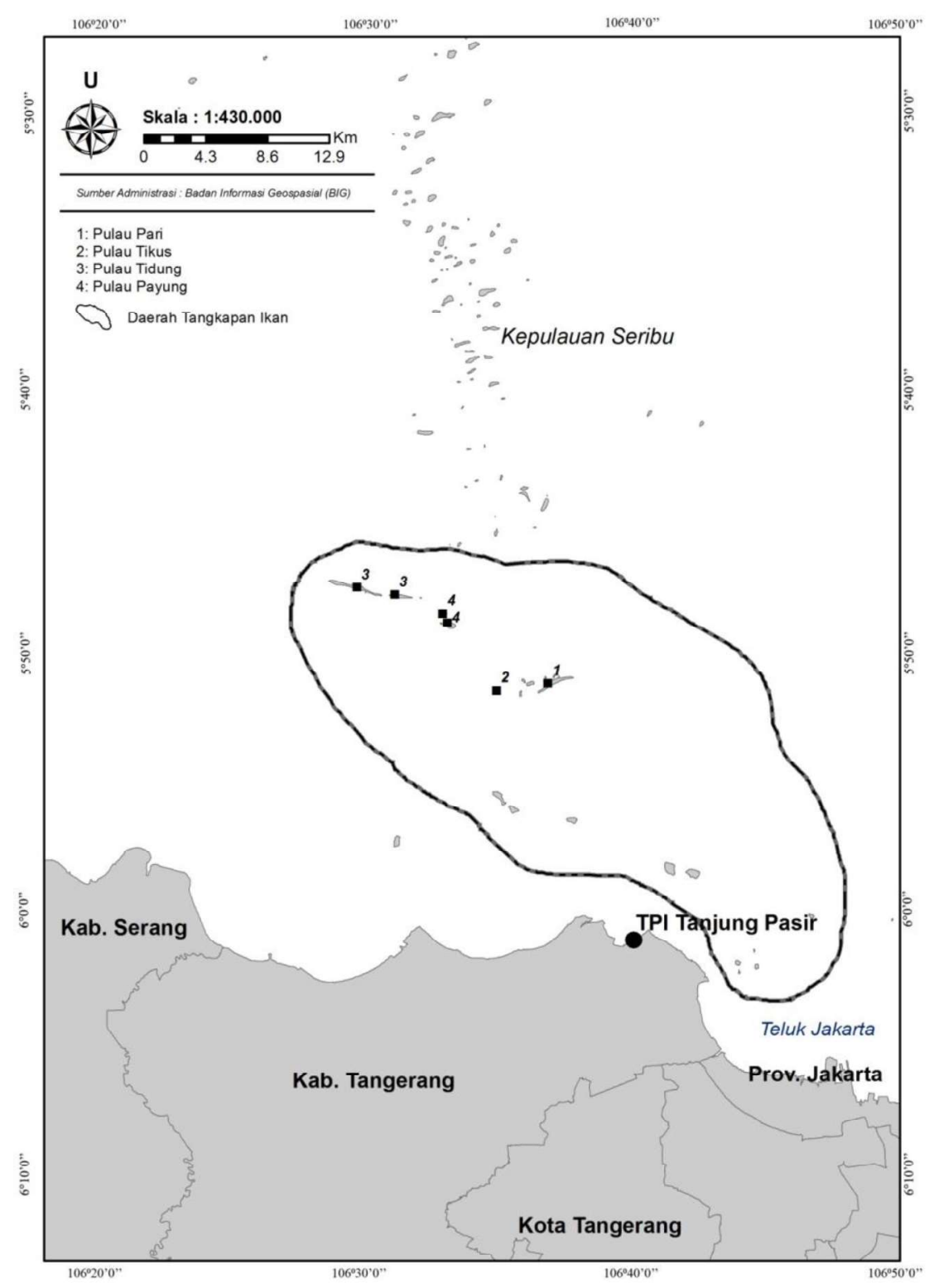

Gambar 1. Lokasi penelitian ikan kakap Lutjanus vitta di Perairan Teluk Jakarta dan sekitarnya

Analisis data yang dilakukan terdiri atas nisbah kelamin, indeks kematangan gonad, pendugaan panjang kali pertama matang gonad (Lm), dan rata-rata panjang tertangkap (Lc).

Nisbah kelamin menunjukkan perbandingan jumlah betina terhadap ikan jantan dalam setiap bulan pengamatan jumlah total ikan. Uji Chisquare pada selang kepercayaan $95 \%(\alpha=0,05)$ dilakukan untuk menguji perbedaan nisbah tersebut mengikuti persamaan berikut:

$$
\chi^{2}=\left[\frac{\Sigma\left(f_{0}-f_{e}\right)^{2}}{f_{e}}\right]
$$

Keterangan: $\chi^{2}=$ nilai chi-square, $f_{0}=$ frekuensi yang diperoleh atau diamati, $\mathrm{f}_{\mathrm{e}}=$ frekuensi yang diharapkan. 
Tabel 1 Tingkat kematangan gonad ikan kakap

\begin{tabular}{|c|c|c|c|}
\hline \multirow{2}{*}{$\begin{array}{l}\text { Tingkat ke- } \\
\text { matangan }\end{array}$} & \multirow{2}{*}{ Keadaan } & \multicolumn{2}{|c|}{ Keterangan } \\
\hline & & Ovari & Testes \\
\hline I & Belum matang & $\begin{array}{l}\text { Ovari kira-kira } 1 / 3 \text { panjang rongga ba- } \\
\text { dan, bening, dan berwarna kemerahan. } \\
\text { Telur tidak terlihat dengan mata telan- } \\
\text { jang. }\end{array}$ & $\begin{array}{l}\text { Testes berukuran } 1 / 3 \text { panjang } \\
\text { rongga badan dan berwarna ke- } \\
\text { putihan. }\end{array}$ \\
\hline II & Perkembangan & $\begin{array}{l}\text { Ovari kira-kira } 1 / 2 \text { panjang rongga ba- } \\
\text { dan, bening/jernih. Telur tidak terlihat } \\
\text { dengan mata telanjang. }\end{array}$ & $\begin{array}{l}\text { Testes berukuran } 1 / 2 \text { panjang } \\
\text { rongga badan dan berwarna ke- } \\
\text { putihan, kurang lebih simetris. }\end{array}$ \\
\hline III & Pematangan & $\begin{array}{l}\text { Ovari kira-kira } 2 / 3 \text { panjang rongga ba- } \\
\text { dan. Ovari berwarna kuning kemerah- } \\
\text { an, kelihatan butiran. }\end{array}$ & $\begin{array}{l}\text { Testes berukuran } 2 / 3 \text { panjang } \\
\text { rongga badan, lembut, dan ber- } \\
\text { warna keputihan sampai krem. }\end{array}$ \\
\hline IV & Matang & $\begin{array}{l}\text { Ovari memenuhi rongga badan dan } \\
\text { berwarna merah jambu/jingga dengan } \\
\text { pembuluh darah yang terlihat jelas di } \\
\text { permukaannya. Terlihat telur yang ma- } \\
\text { sak dan tembus cahaya. }\end{array}$ & $\begin{array}{l}\text { Testes memenuhi rongga badan } \\
\text { dan berwarna keputihan } / \text { krem } \\
\text { dan lembut. }\end{array}$ \\
\hline V & Mijah salin & $\begin{array}{l}\text { Ovari mengerut sampai menjadi kira- } \\
\text { kira } 1 / 2 \text { panjang rongga badan. Ovari } \\
\text { dapat mengandung sisa-sisa telur, ge- } \\
\text { lap atau jernih. }\end{array}$ & $\begin{array}{l}\text { Testes mengerut sampai menja- } \\
\text { di } 1 / 2 \text { panjang rongga badan. } \\
\text { Dinding-dinding kendur. }\end{array}$ \\
\hline
\end{tabular}

Sumber: Holden \& Raitt (1974)

Indeks kematangan gonad (IKG) merupakan suatu analisis yang didasarkan pada gonad dan bobot tubuh ikan secara keseluruhan. Nilai IKG diperoleh melalui rumus (Effendie 1997):

$$
\mathrm{IKG}=\frac{\mathrm{W}_{\mathrm{g}}}{\mathrm{W}} \times 100
$$

Keterangan: $\mathrm{IKG}=$ indeks kematangan gonad, $\mathrm{W}_{\mathrm{g}}=$ bobot gonad (g), W= bobot tubuh ikan (g).

Panjang ikan kali pertama matang gonad (Lm) dianalisis dengan metode Spearman Karber (Udupa 1986) dengan selang kepercayaan 95\% $(\alpha=0,05)$, mengikuti rumus sebagai berikut:

$\mathrm{m}=\left[\mathrm{xk}+\left(\frac{\mathrm{x}}{2}\right)\right]-\left(\mathrm{x} \sum \mathrm{p}_{\mathrm{i}}\right)$

$\operatorname{antilog} m(M)=m \pm 1,96 \sqrt{\operatorname{var}(m)}$

Keterangan: $m=\log$ panjang ikan pada kematangan gonad pertama, $x k=\log$ nilai tengah kelas panjang yang terakhir ikan yang telah matang gonad, $x=\log$ pertambahan panjang pada nilai tengah, $\mathrm{p}_{\mathrm{i}}=$ proporsi ikan matang gonad pada kelas panjang ke-I, $M=$ panjang ikan kali pertama matang gonad.
Perhitungan nilai Lc diperoleh dengan cara memplotkan frekuensi kumulatif ikan yang tertangkap dengan panjang cagak, akan diperoleh kurva logistik baku. Titik perpotongan antara kurva logistik baku dengan 50\% frekuensi kumulatif merupakan nilai rata-rata panjang ikan yang tertangkap (Wujdi et al. 2013, Wahyuningsih et al. 2013).

\section{Hasil}

Ikan kakap L. vitta merupakan jenis ikan dari marga Lutjanus dan suku Lutjanidae. Ciri umum marga ini adalah memiliki badan yang agak tinggi dan pipih. Ciri khusus yang dimiliki oleh L.vitta adalah adanya garis kehitaman yang terletak di bagian tengah badan dari belakang mata hingga bagian atas batang ekor (Anderson \& Allen 2001). Terdapat 10 duri keras dan 12-13 duri lemah pada sirip punggung, 3 duri keras dan 8-9 duri lemah pada sirip dubur serta 15-16 duri 
lemah pada sirip dada. Bentuk sirip ekor adalah lengkung tunggal dengan tubuh berwarna merah muda dan putih pada bagian perut (Gambar 2).

Jumlah ikan contoh yang dikumpulkan setiap bulannya berkisar antara 30-60 ekor. Secara keseluruhan, total contoh ikan kakap adalah 282 ekor yang terdiri atas 126 ekor jantan, 151 ekor betina, dan 5 ekor yang tidak dapat ditentukan jenis kelaminnya. Panjang cagak ikan kakap jantan berkisar antara 148,1-264,8 mm, sedangkan bobot tubuh dari 54,3-315,2 g. Kisaran panjang cagak ikan kakap betina adalah 132,2-247,6 mm dan bobot tubuh berkisar antara 34,6-233,1 gram. Modus ukuran panjang cagak ikan kakap jantan dan betina berada pada kisaran 185,4-198,6 mm (Gambar 3).

Secara umum, nisbah kelamin ikan kakap betina dan jantan adalah 1,2:1 atau 55\% ikan betina berbanding $45 \%$ ikan jantan. Perhitungan ini dilakukan untuk seluruh ikan contoh, baik yang belum ataupun sudah matang gonad. Ikan kakap betina lebih banyak tertangkap dibandingkan dengan ikan kakap jantan, kecuali pada bulan April dan September (Tabel 2). Berdasarkan perhitungan, diperoleh nilai khi kuadrat sebesar 1,37 yang lebih kecil daripada nilai tabel khi kuadrat pada selang kepercayaan 95\% $(11,07)$. Nilai ini menunjukkan bahwa nisbah kelamin ikan kakap dalam kondisi seimbang.

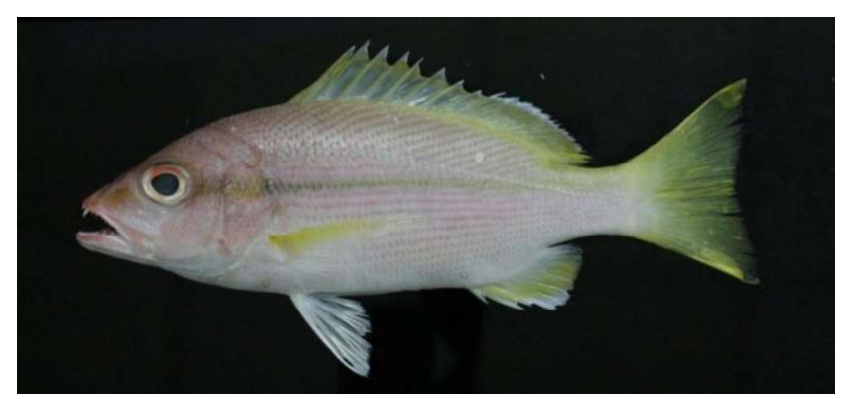

Gambar 2. Ikan kakap Lutjanus vitta di Perairan Teluk Jakarta dan sekitarnya (FL: 172 mm)

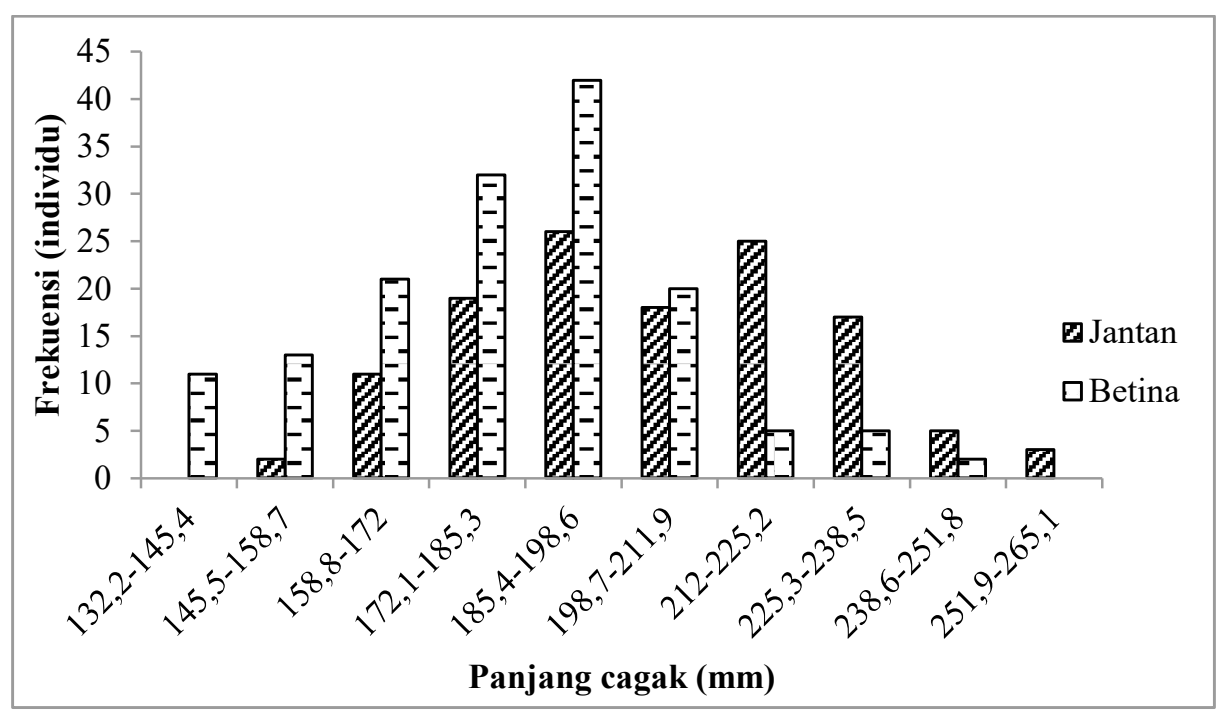

Gambar 3. Sebaran frekuensi panjang cagak ikan kakap di Teluk Jakarta dan sekitarnya pada bulan April, Mei, Agustus, September, Oktober 2014, dan Januari 2015 
Tabel 2. Nisbah betina terhadap jantan ikan kakap di Teluk Jakarta dan sekitarnya pada bulan bulan April, Mei, Agustus, September, Oktober 2014 dan Januari 2015

\begin{tabular}{lccccccc}
\hline \multirow{2}{*}{ Kelamin } & \multicolumn{9}{c}{ Bulan } & \multirow{2}{*}{ Total } \\
\cline { 2 - 7 } & April & Mei & Agustus & September & Oktober & Januari & \\
\hline Betina (ekor) & 15 & 33 & 21 & 22 & 23 & 37 & 151 \\
Jantan (ekor) & 20 & 27 & 15 & 24 & 16 & 24 & 126 \\
\hline Nisbah & 0,75 & 1,22 & 1,40 & 0,92 & 1,44 & 1,54 & 1,20 \\
\hline
\end{tabular}

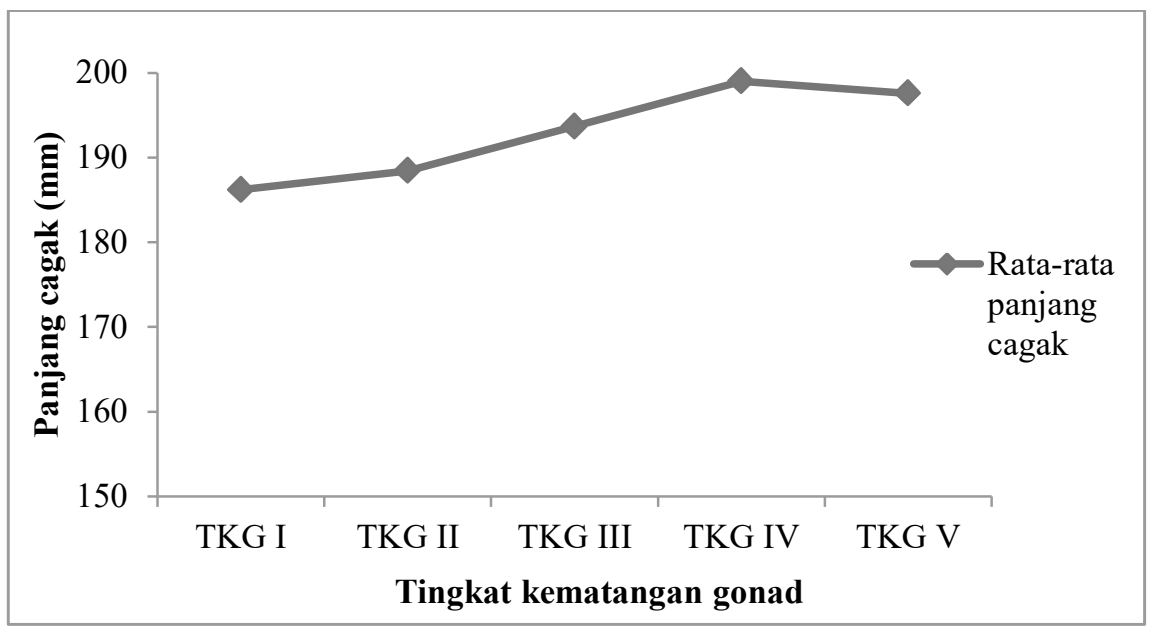

Gambar 4. Hubungan antara tingkat kematangan gonad dan panjang cagak ikan kakap di Teluk Jakarta dan sekitarnya

Berdasarkan Gambar 4, diketahui bahwa terdapat hubungan antara ukuran panjang cagak ikan dengan tingkat kematangan gonadnya. TKG ikan akan semakin berkembang dengan meningkatnya ukuran ikan. Ikan kakap jantan dan betina yang diamati selama penelitian banyak yang belum matang gonad dengan jumlah 113 ekor atau 90\% (jantan) dan 70 ekor atau $47 \%$ (betina). Pada bulan Agustus hingga Oktober diperoleh ikan kakap jantan dan betina pada fase TKG III dan IV (Gambar 5). Hal ini menunjukkan pada bulan tersebut gonad ikan kakap telah matang dan siap melakukan pemijahan. Selain itu, fase tersebut juga banyak ditemukan pada ikan kakap betina pada Bulan Mei.

Nilai indeks kematangan gonad berfluktuasi setiap bulan pengamatan (Gambar 6). Nilai IKG rata-rata bulanan ikan jantan berkisar antara 0,2-
0,8 dan ikan betina memiliki kisaran nilai 1-2 . Selama pengamatan, perkembangan IKG ikan kakap jantan tertinggi terjadi pada bulan Agustus, sedangkan ikan betina berada di bulan September. Pada bulan Juni, Juli, November, dan Desember tidak dilakukan pengambilan contoh, sehingga nilai IKG pada bulan tersebut tidak diketahui.

Pengukuran rata-rata ukuran panjang cagak ikan kakap yang tertangkap pada tingkat kemungkinan 50\% (Lc) adalah 178 mm (Gambar 7). Sementara itu, berdasarkan analisis SpearmanKarber (Udupa 1986) diketahui bahwa panjang cagak ikan kakap kali pertama matang gonad (Lm) di Perairan Teluk Jakarta dan sekitarnya adalah $252 \mathrm{~mm}$ dengan kisaran 243-260 mm (jantan) dan $187 \mathrm{~mm}$ dengan kisaran 177-196 mm (betina). 


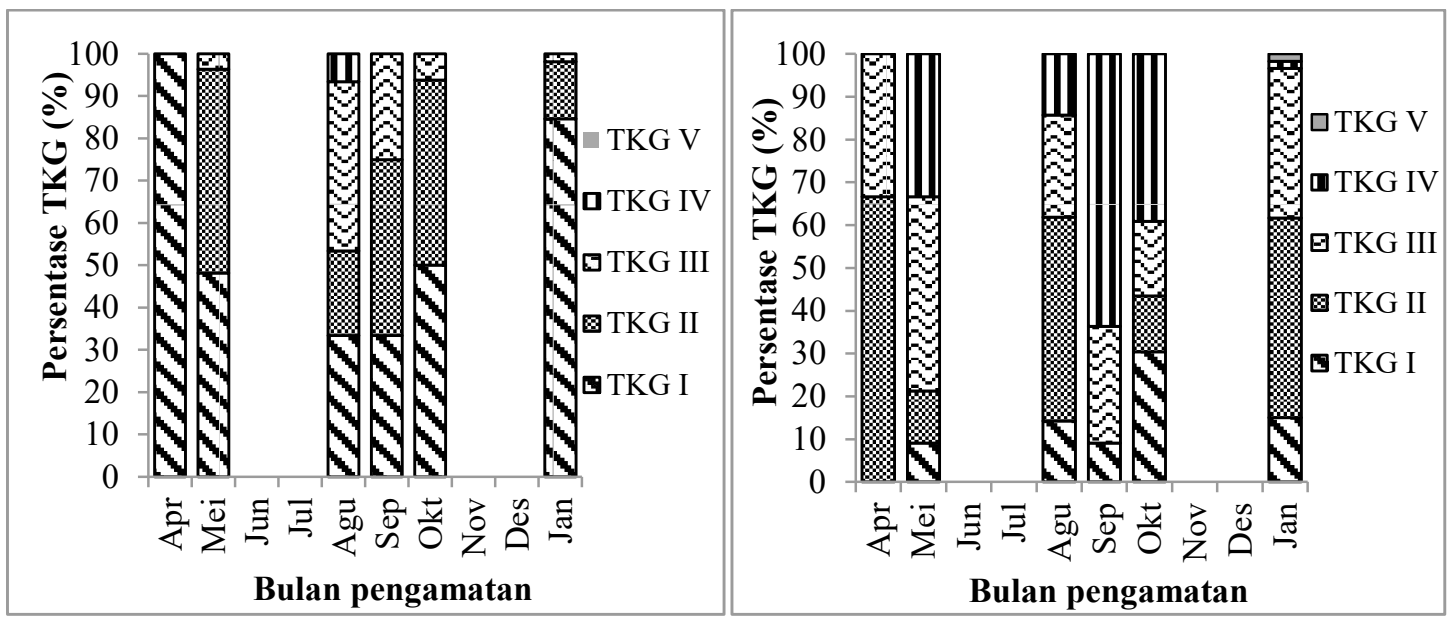

b

Gambar 5. Tingkat kematangan gonad ikan kakap jantan (a) dan betina (b) di Teluk Jakarta dan sekitarnya

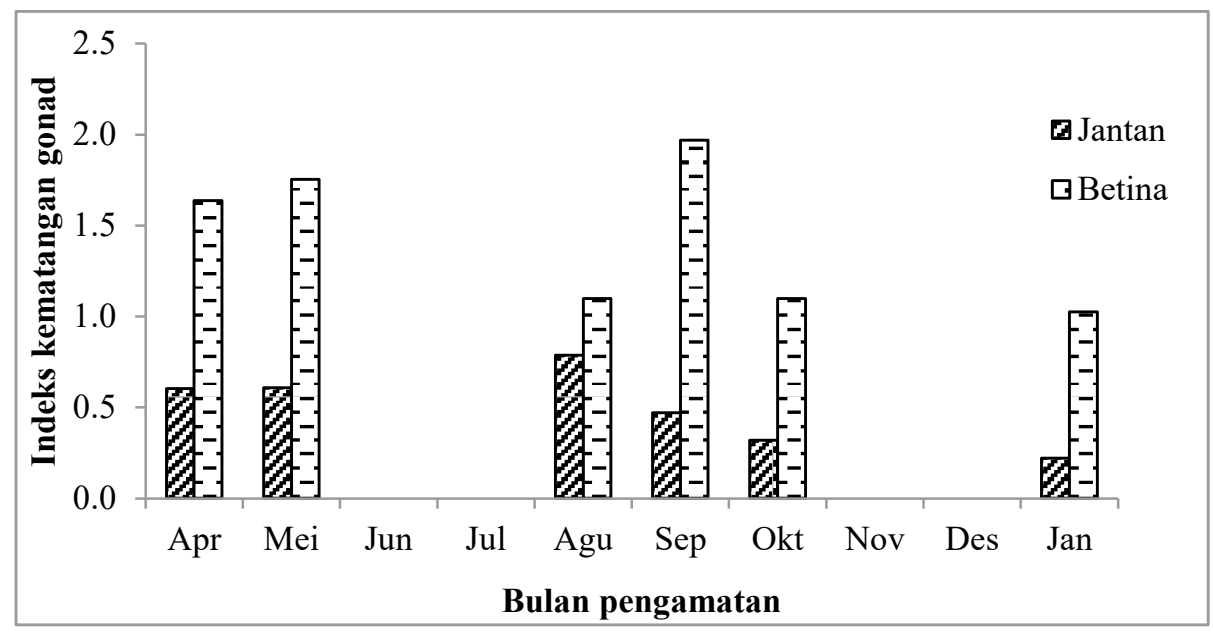

Gambar 6. Indeks kematangan gonad ikan kakap di Teluk Jakarta dan sekitarnya

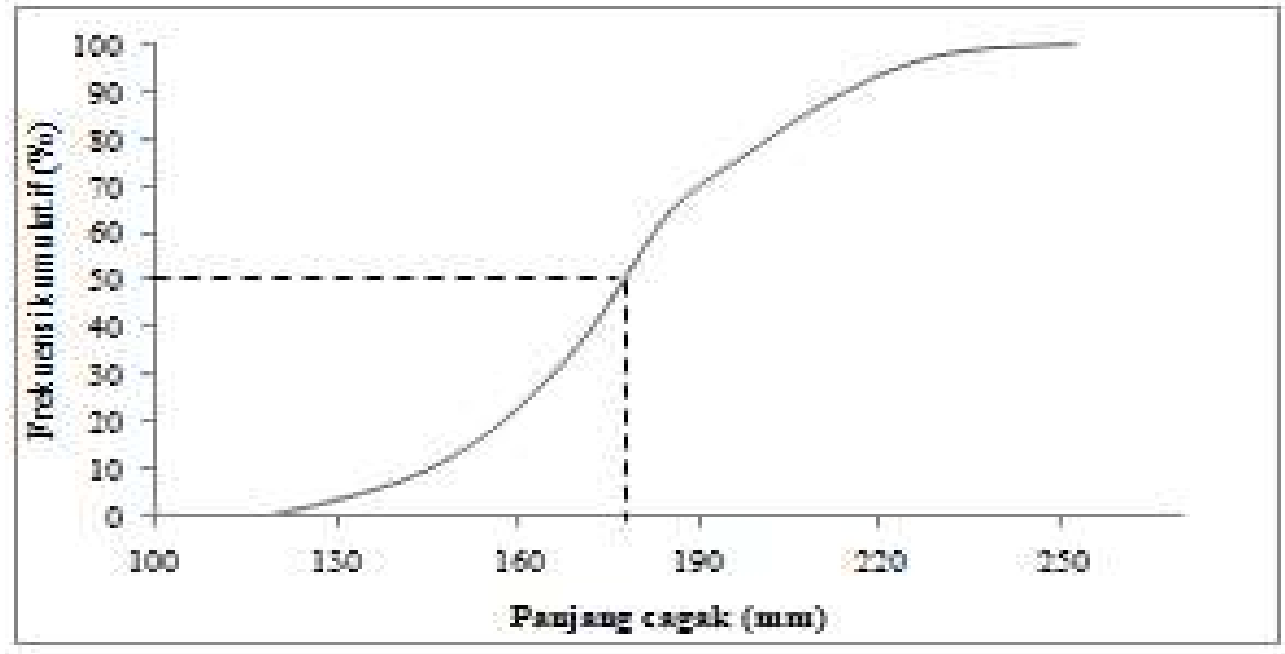

Gambar 7. Frekuensi kumulatif sebaran panjang cagak ikan kakap di Teluk Jakarta dan sekitarnya 


\section{Pembahasan}

Kisaran panjang cagak ikan kakap yang diperoleh dalam penelitian ini adalah 132-265 mm. Menurut Anderson \& Allen (2001), pada umumnya ikan kakap berukuran $250 \mathrm{~mm}$ dengan ukuran panjang maksimum $400 \mathrm{~mm}$. Ikan-ikan yang ditangkap di Teluk Jakarta dan sekitarnya dominan berukuran kecil. Tidak jauh berbeda dengan hasil penelitian ini, kisaran panjang cagak ikan kakap di Pusat Karang Penghalang Besar (Great Barrier Reef), Australia adalah 175-274 mm (Newman et al. 2000). Sementara itu, ikan kakap di pesisir Barat Daya India memiliki kisaran panjang total yang lebih besar, yaitu 90318 mm (Ramachandran et al. 2013). Menurut Frédou \& Ferreira (2005), perbedaan distribusi ikan contoh yang diamati dapat disebabkan oleh adanya dampak kegiatan eksploitasi perikanan, perbedaan karakteristik ekologi setiap perairan serta jenis dan selektivitas alat tangkap. Pada umumnya alat tangkap yang digunakan dalam setiap penelitian cenderung berbeda, seperti pancing rawai dengan ukuran mata pancing kecil (penelitian ini), perangkap ikan dan pancing ulur (di Pusat Karang Penghalang Besar, Australia) serta jaring dasar dengan ukuran mata jaring 30 mm (di pesisir Barat Daya India). Karakteristik dan selektivitas yang berbeda pada setiap alat tangkap dapat menghasilkan perbedaan struktur ukuran ikan yang ditangkap (Al-Rasady et al. 2012, Wujdi et al. 2013). Selain itu, adanya perbedaan faktor biologi ikan seperti kondisi fisiologis, umur, jenis kelamin, keturunan dan energi serta kondisi lingkungan pada masing-masing perairan juga dapat menimbulkan variasi ukuran panjang ikan, karena akan memengaruhi cepat lambatnya pertumbuhan ikan (Effendie 1997, Fry \& Milton 2009, Restiangsih et al. 2016, Schwartzkopf \& Cowan Jr 2017).
Nisbah kelamin merupakan salah satu variabel riwayat hidup (life history) yang sangat penting dan menjadi dasar dalam menilai kemampuan atau kebugaran suatu populasi ikan (Winemiller \& Rose 1992). Variabel ini digunakan untuk memperlihatkan perbandingan jantan dan betina dalam suatu populasi. Untuk mempertahankan kelangsungan hidup dan terjaganya kelestarian dalam suatu populasi, idealnya nisbah jenis kelamin berada pada keadaan seimbang atau jumlah ikan betina lebih banyak (Bal \& Rao 1984). Hasil uji khi kuadrat menunjukkan bahwa perbandingan antara ikan kakap jantan dan betina di perairan Teluk Jakarta dan sekitarnya dalam keadaan yang seimbang. Namun, jenis ikan lainnya dari suku Lutjanidae (Aphareus rutilans) di Palabuhan Ratu memiliki nisbah kelamin yang tidak seimbang (Hukom et al. 2006). Adanya perbedaan dalam perbandingan kelamin ini dapat disebabkan oleh beberapa hal, seperti perbedaan tingkah laku, kondisi lingkungan, kegiatan penangkapan, perbedaan laju kematian, distribusi dan pertumbuhan ikan serta kemampuan reproduksi (Bal \& Rao 1984, Effendie 1997, Turkmen et al. 2002). Selain itu, adanya perbedaan migrasi selama dan sebelum musim pemijahan juga diduga memengaruhi nisbah kelamin ikan kakap (Thomas \& Munro 1983).

Peningkatan nilai IKG akan berbanding lurus dengan perkembangan TKG (Hukom et al. 2006), artinya ikan yang telah matang gonad akan memiliki nilai IKG yang besar dan begitu sebaliknya. TKG yang semakin berkembang akan menghasilkan ukuran gonad yang semakin besar, sehingga berdampak pada besarnya nilai IKG setiap individu ikan (Wujdi et al. 2013) Rendahnya nilai IKG rata-rata yang diperoleh selama penelitian menunjukkan bahwa ikan-ikan yang diamati sebagian besar masih berukuran kecil atau belum matang gonad (Gambar 6). Hal 
ini juga terjadi pada penelitian ikan jenis lain pada suku Lutjanidae, yaitu ikan kakap merah $L$. sanguineus dan L. malabaricus di Laut Jawa (Karyaningsih \& Suhendrata 1992; Wahyuningsih et al. 2013) dan ikan tajuk Aphareus rutilans di Palabuhan Ratu (Hukom et al. 2006), ikanikan yang ditangkap didominasi oleh ikan yang belum matang gonad. Menurut Johannes (1978), ikan-ikan suku Lutjanidae merupakan jenis ikan yang beruaya pada saat melakukan pemijahan dan biasanya memijah di laguna atau lereng terumbu karang yang menghadap ke laut lepas. Oleh karena itu, ada kemungkinan bahwa daerah penangkapan ikan oleh nelayan Tanjung Pasir bukan menjadi daerah pemijahan ikan kakap, sehingga ikan yang telah matang gonad jarang ditemukan dalam jumlah besar. Namun, untuk membuktikan hal tersebut perlu dilakukan penenelitian lebih lanjut, terlebih terkait strategi reproduksinya.

Ukuran pertama matang gonad (Lm) ikan kakap betina lebih kecil daripada ikan kakap jantan, yaitu $187 \mathrm{~mm}$. Pada umumnya ikan betina akan mengeluarkan energi yang lebih tinggi untuk pertumbuhan gonad daripada pertumbuhan sel atau somatiknya, sehingga ikan betina akan lebih cepat matang gonad dibandingkan ikan jan$\tan$ (Clarke 1983, West 1990; King 1995; Effendie 1997). Selain itu, ikan betina berpotensi kehilangan hingga $85 \%$ cadangan energi somatik saat pemijahan terjadi (Adams \& Breck 1990). Pertumbuhan dan pematangan gonad pada individu dewasa merupakan dua proses utama yang membutuhkan banyak energi dan terjadi dengan mengorbankan pertumbuhan jaringan somatik (Flath \& Diana 1985). Di pesisir Barat Daya India, nilai Lm pada ikan kakap betina adalah $158 \mathrm{~mm}$ dan $145 \mathrm{~mm}$ untuk ikan kakap jantan (Ramachandran et al. 2013). Pada umumnya, kelompok ikan kakap mencapai ukuran kema- tangan gonad pada ukuran panjang 40-50\% dari panjang maksimumnya dan perbedaan ukuran pada saat matang gonad biasanya dipengaruhi oleh kedalaman, tipe habitat dan kelimpahan makanan (Grimes 1987). Nilai Lm dapat berbeda dalam satu jenis ikan dan antar jenis ikan, sehingga individu yang berasal dari satu kelas umur atau satu kelas panjang tidak selalu harus mencapai panjang kali pertama matang gonad yang sama (Udupa 1986). Sebagai salah satu karakteristik riwayat hidup ikan, nilai Lm sangat penting untuk diketahui karena dapat berimplikasi pada keakuratan suatu kegiatan pengelolaan perikanan (Fry et al. 2009).

Hasil analisis terhadap nilai Lc dan Lm menunjukkan bahwa sebagian besar ikan kakap yang tertangkap di Perairan Teluk Jakarta dan sekitarnya masih muda dan belum memijah atau belum matang gonad (Lc $<$ Lm). Jika ikan-ikan yang berukuran kecil dan belum matang gonad lebih banyak tertangkap, maka berpeluang menyebabkan terjadinya lebih-tangkap pertumbuhan (growth overfishing). Jenis lebih-tangkap ini akan menyebabkan penurunan stok ikan akibat banyaknya penangkapan ikan-ikan muda, yang belum sempat mencapai ukuran tertentu atau dewasa sehingga tidak bisa mengimbangi penyusutan stok karena kematian alami (misalnya pemangsaan).

Berdasarkan informasi di atas, maka upaya pengelolaan ikan kakap yang dapat dilakukan meliputi peningkatan selektivitas alat tangkap dan peningkatan ukuran tangkap. Pendekatan selektivitas alat tangkap dapat dilakukan melalui peningkatan ukuran mata pancing (di bawah nomor 13) agar ukuran tangkap ikan kakap menjadi lebih panjang daripada nilai $\mathrm{Lm}$, yaitu $250 \mathrm{~mm}$. Peningkatan ukuran tangkap ini juga dimaksudkan agar ikan yang tertangkap mencapai struktur umur yang paling produktif dari stok ikan serta 
memberikan kesempatan ikan muda untuk tumbuh sehingga nilai ekonominya bertambah (Muhammad 2011).

\section{Simpulan}

Ikan kakap yang tertangkap di sekitar Perairan Teluk Jakarta dan sekitarnya memiliki kisaran panjang cagak 132-265 mm. Sebagian besar ikan yang tertangkap belum mencapai ukuran kali pertama matang gonad $(\mathrm{Lc}<\mathrm{Lm})$. Ukuran panjang cagak rata-rata tertangkap (Lc) adalah $178 \mathrm{~mm}$, sedangkan panjang cagak kali pertama matang gonad (Lm) adalah $252 \mathrm{~mm}$ (jantan) dan $187 \mathrm{~mm}$ (betina).

\section{Persantunan}

Penulis mengucapkan terima kasih kepada M. Adrim, Fahmi, Priyo Agustono, dan Johan Picasouw atas segala bantuan yang telah diberikan selama penelitian.

\section{Daftar pustaka}

Adams SM, Breck JE. 1990. Bioenergetics. In: Schreck CB, Moyle PB (eds). Methods for Fish Biology. American Fisheries Society, Bethesda. pp. 389-409.

Al-Rasady I, Govender A, Saud M, Al-Jufaili. 2012. Reproductive biology of longnose trevally (Carangoides chrysophrys) in the Arabian Sea, Oman. Environmental Biology of Fishes, 93 (1): 177-184.

Anderson WD, Allen GR. 2001. Lutjanidae. Snappers (jobfishes). In: Carpenter KE, Niem V (eds.). FAO species identification guide for fishery purposes. The living marine resources of the Western Central $\mathrm{Pa}$ cific. Vol. 5. Bony fishes part 3 (Menidae to Pomacentridae). FAO, Rome. pp. 2840-2919.

Bal DV, Rao KV. 1984. Marine Fisheries of India. Tata McGraw-Hill Publishing Company, New Delhi. 472 p.

Clarke TA. 1983. Sex ratios and sexual differences in size among mesopelagic fishes from the Central Pasific Ocean. Marine Biology, 73(2): 203-209.
Davis TLO, West GJ. 1992. Growth and mortality of Lutjanus vittus (Quoy and Gaimard) from the North West Shelf of Australia. Fishery Bulletin, 90(2): 395-404.

Davis TLO, West GJ. 1993. Maturation, reproductive seasonality, fecundity, and spawning frequency in Lutjanus vitta (Quoy and Gaimard) from the North West Shelf of Australia. Fishery Bulletin, 91(1): 224-236

Effendie MI. 1997. Biologi Perikanan. Yayasan Pustaka Nusatama, Yogyakarta. 162 hlm.

Flath LE, Diana JS. 1985. Seasonal energy dynamics of the alewife in Southeastern Lake Michigan. Transactions of the Amarican Fisheries Society, 114(3): 328-337.

Frédou T, Ferreira BP. 2005 Bathymetric trends of Northeastern Brazilian snappers (Pisces, Lutjanidae): implications for the reef fishery dynamic. Brazilian Archives of Biology and Technology, 48(1): 787-800.

Fry G, Milton DA, Velde TVD, Stobutzki I, Andamari R, Badrudin, Sumiono B. 2009. Reproductive dynamics and nursery habitat preferences of two commercially important Indo-Pacific red snappers Lutjanus erythropterus and L. malabaricus. Fisheries Sciences, 75(1): 145-158.

Fry GC, Milton DA. 2009. Age, growth and mortality estimates for populations of red snappers Lutjanus erythropterus and $L$. malabaricus from northern Australia and eastern Indonesia. Fisheries Sciences, 75(5): 1219-1229.

Grimes CB. 1987. Reproductive biology of Lutjanidae: a review. In: Polovina JJ, Ralston $\mathrm{S}$ (ed.). Tropical snappers and groupers: biology and fisheries management. Westview Press, Boulder and London. pp. 239294.

Holden MJ, Raitt DFS. 1974. Manual of Fisheries Science. FAO Fisheries Technical Papers 115. 214 p.

Hukom FD, Purnama DR, Rahardjo MF. 2006. Tingkat kematangan gonad, faktor kondisi, dan hubungan panjang-berat ikan tajuk (Aphareus rutilans Cuvier, 1830) di perairan Laut Dalam Palabuhanratu, Jawa Barat. Jurnal Iktiologi Indonesia, 6(1): 1-9.

Johannes RE. 1978. Reproductive strategies of coastal marine fishes in the tropics. Environmental Biology of Fishes, 3(1): 65-84. 
Karyaningsih S, Suhendrata T. 1992. Pendugaan ukuran pertama kali matang gonad ikan kakap merah (Lutjanus sanguineus) di Laut Jawa. Jurnal Penelitian Perikanan Laut, 75(1): 29-32.

King MG.1995. Fisheries biology, assessment and management. Fishing News Books, Oxford. $341 \mathrm{p}$.

Muhammad S. 2011. Kebijakan Pembangunan Perikanan dan Kelautan: Pendekatan Sistem. Universitas Brawijaya Press. Malang. $508 \mathrm{hlm}$.

Newman SJ, Williams DMcB. 1996. Variation in reef associated assemblages of the Lutjanidae and Lethrinidae at different distances offshore in the central Great Barrier Reef. Environmental Biology of Fishes, 46(2): 123-138.

Newman SJ, Cappo M, Williams D.McB. 2000. Age, growth and mortality of the stripey, Lutjanus carponotatus (Richardon) and the brown-stripw snapper, L. vitta (Quoy and Guimard) from the central Great Barrier Reef, Australia. Fisheries Research, 48(1): 263-275.

Ramachandran S, Ali DM, Varghese BC. 2013. Age, growth and maturity of brownstripe red snapper Lutjanus vitta (Quoy \& Gaimard, 1824) from southwest coast of India. Journal of Marine Biology, 55(2): 61-68.

Randall JE. 1995. Coastal Fishes of Oman. University of Hawaii Press, Honolulu. 439 p.

Restiangsih YH, Noegroho T, Wagiyo K. 2016. Beberapa aspek biologi ikan tenggiri papan (Scomberomorus guttatus) di perairan Cilacap dan sekitarnya. Bawal, 8(3): 191198
Schwartzkopf BD, Cowan Jr JH. 2017. Seasonal and sex differences in energy reserves of red snapper Lutjanus campechanus on natural and artificial reefs in the northwestern Gulf of Mexico. Fisheries Science, 83(1): 13-22.

Thomas R, Munro JL. 1983. The biology, ecology and bionomics of the snappers, Lutjanidae. ICLARM. Technical Report, 7: 94109.

Turkmen M, Erdogan O, Yildrim A, Akhyurt I. 2002. Reproductive tactics, age and growth of Capoeta capoeta umla Heckel 1843 from the Askale region of the Karasu River, Turkey. Fisheries Research, 54(1): 317-328

Udupa KS. 1986. Statistical method of estimating the size at first maturity of fishes. Fishbyte, 4(2): 8-10.

Wahyuningsih, Prihatiningsih, Ernawati T. 2013. Parameter populasi ikan kakap merah (Lutjanus malabaricus) di Perairan Laut Jawa bagian timur. Bawal, 5(3): 175-179.

West G. 1990. Methods of assessing ovarian development in fishes: a review. Australian Journal of Marine and Freshwater Research, 41(1): 199-222

Wujdi A, Suwarso, Wudianto. 2013. Biologi reproduksi dan musim pemijahan ikan lemuru (Sardinella lemuru Bleeker, 1853) di Perairan Selat Bali. Bawal, 5 (1): 49-57.

Winemiller KO, Rose KA. 1992. Patterns of lifehistory diversification in North American fishes: implications for population regulations. Canadian Journal of Fisheries and Aquatic Sciences, 49(10): 2196-2218. 